\title{
Management of Premature Labour in Diabetic Pregnancy
}

\author{
A. H. Barnett, S. M. Stubbs, and A. M. Mander \\ Diabetic and Obstetric Departments, King's College Hospital, London, England
}

\begin{abstract}
Summary. The practical management of premature labour is described, illustrated by ten cases. All the patients were treated with $\beta$-sympathomimetic infusion, either salbutamol $(0.4-1.6 \mathrm{mg} / \mathrm{h})$ or ritodrine hydrochloride $(2-6 \mathrm{mg} / \mathrm{h})$, to stop uterine contractions, and with intramuscular dexamethasone $4 \mathrm{mg}$ eight hourly to accelerate foetal lung maturity. Satisfactory control of blood glucose was achieved (range $2-10 \mathrm{mmol} / \mathrm{l}$ ) by using high rates of insulin infusion (range 8-32 units per hour). Delivery was postponed in eight cases and seven healthy babies were born. There were three foetal deaths from multiple congenital abnormalities. $\beta$-sympathomimetic infusion caused few maternal side-effects and there were no foetal problems. Maternal plasma potassium decreased in all cases studied, the mean fall being from $4.5 \mathrm{mmol} / 1$ to $2.7 \mathrm{mmol} / 1$.
\end{abstract}

Key words: Premature labour, diabetes, B-sympathomimetic infusion, salbutamol, ritodrine hydrochloride, dexamethasone, insulin infusion, potassium, maternal and foetal wellbeing.

Premature labour in diabetic pregnancy constitutes an emergency, and confusion still reigns regarding appropriate management. Prematurity in diabetics is especially to be avoided because of the danger of respiratory distress syndrome. $\beta$-sympathomimetic agents are used to prevent premature delivery by suppressing uterine contractions and their effectiveness is well established $[1,2,3]$, but they have significant cardiac and metabolic effects which may cause serious difficulties in diabetics $[4,5,6]$.

The purpose of this paper is to describe a simple system for the management of premature labour in diabetic pregnancy as a guide to others faced with this problem.

\section{Patients and Methods}

Ten cases of premature labour in diabetics have been managed during the past two years. All were given both intramuscular dexamethasone $4 \mathrm{mg} 8$ hourly to promote foetal lung maturity, and a $\beta$ sympathomimetic agent to stop uterine contractions. Two patients were emergency referrals from other hospitals. The other eight had been cared for in our own diabetic obstetric clinic. One patient developed co-incident mild pre-eclampsia from 28 weeks of pregnancy and at the time of development of premature contractions was taking methyldopa $250 \mathrm{mg}$ tds. The other 9 patients were healthy and not on any medication apart from insulin. Two of the patients were classified as class $B$, seven as class $C$ and one as class D according to White's Classification [7].

Pre-admission diabetic control in eight cases was good with most measured pre-prandial blood glucose values below $7 \mathrm{mmol} / \mathrm{l}$, these being determined both in the clinic and with home blood glucose monitoring. One case, however, had persistent poor control with preprandial blood glucose as high as $14 \mathrm{mmol} / \mathrm{l}$ necessitating a number of admissions to hospital. No information about pre-admission control was available on one of the referred patients.

\section{Regimen Used}

As soon as premature labour threatened an infusion of soluble insulin given by an infusion pump was begun, the syringe containing insulin $2 \mathrm{U} / \mathrm{ml}$ in $0.154 \mathrm{~mol} / 1$ saline. The pump used was either the Meltec, marketed by Milton Roy Medical, or the Dylade Sage Infusion Pump, marketed by Dylade Co. Ltd. The insulin infusion rate was $16 \mathrm{U} / \mathrm{h}$ from the start of $\beta$-sympathomimetic infusion. Salbutamol infusion was used in eight cases and ritodrine hydrochloride in two, the concentration being $10 \mathrm{mg}$ salbutamol or $50 \mathrm{mg}$ ritodrine hydrochloride in one litre of $0.154 \mathrm{mmol} / 1$ saline. Glucose $(5 \mathrm{~g} / 100 \mathrm{ml})$ rather than saline was used if the patient was not eating. Salbutamol was infused at a rate of $0.4 \mathrm{mg} / \mathrm{h}$ initially and increased in increments of $0.4 \mathrm{mg} / \mathrm{h}$ up to a maximum of $1.6 \mathrm{mg} / \mathrm{h}$ or until uterine contractions ceased. For ritodrine hydrochloride the starting infusion rate was $2 \mathrm{mg} / \mathrm{h}$ increasing to $8 \mathrm{mg} / \mathrm{h}$ or until uterine contractions ceased. In all cases potassium supplements were added to the infusion fluid so that $80 \mathrm{mmol}$ was given over $24 \mathrm{~h}$. Blood glucose was monitored by hourly Dextrostix read with an Ames meter throughout the period of administration of the $\beta$-sympathomimetic agent. Insulin infusion rate was adjusted according to blood glucose concentration to maintain blood glucose between 3 and $7 \mathrm{mmol} / 1$.

During this time maternal blood pressure, pulse, uterine contractions and foetal heart rate were monitored. 
Table 1. Summary of management and outcome of ten cases of premature labour occurring in diabetic pregnancy

\begin{tabular}{|c|c|c|c|c|c|c|c|c|}
\hline Patients & $\begin{array}{l}\text { Time of } \\
\text { pre-term } \\
\text { labour } \\
\text { (weeks of } \\
\text { preg- } \\
\text { nancy) }\end{array}$ & $\begin{array}{l}\text { Time of } \\
\text { delivery } \\
\text { (weeks) }\end{array}$ & $\begin{array}{l}\text { Foetal } \\
\text { sur- } \\
\text { vival }\end{array}$ & $\begin{array}{l}\text { Duration } \\
\text { of B-sym- } \\
\text { patho- } \\
\text { mimetic } \\
\text { infusion } \\
\text { (h) }\end{array}$ & $\begin{array}{l}\text { Maximum } \\
\text { infusion } \\
\text { rate of } \\
\text { B-sym- } \\
\text { patho- } \\
\text { mimetic } \\
(\mathrm{mg} / \mathrm{h})\end{array}$ & $\begin{array}{l}\text { Blood } \\
\text { glucose } \\
\text { at onset } \\
\text { of B-sym- } \\
\text { patho- } \\
\text { mimetic } \\
\text { infusion } \\
\text { (mmol/l) }\end{array}$ & $\begin{array}{l}\text { Mean } \\
\text { blood } \\
\text { glucose } \\
\text { during } \\
\text { B-sym- } \\
\text { patho- } \\
\text { mimetic } \\
\text { infusion } \\
\text { (mmol/1, } \\
\text { mean } \pm \mathrm{SD} \text { ) }\end{array}$ & $\begin{array}{l}\text { Insulin } \\
\text { require- } \\
\text { ments at } \\
\text { maximum } \\
\text { B-sym- } \\
\text { patho- } \\
\text { mimetic } \\
\text { infusion } \\
(\mathrm{U} / \mathrm{h})\end{array}$ \\
\hline 1 & 30 & 32 & $\mathrm{No}^{\mathrm{a}}$ & 72 & 1.6 & 4.8 & $5.5 \pm 2.0$ & 10 \\
\hline 2 & 32 & 38 & Yes & 24 & $6.0^{\mathrm{b}}$ & 5.3 & $6.8 \pm 2.2$ & 8 \\
\hline 3 & 31 & 37 & Yes & 20 & 0.4 & 4.5 & $6.0 \pm 3.0$ & 10 \\
\hline 4 & 33 & 35 & Yes & 16 & 1.2 & not known & $6.0 \pm 2.7^{\mathrm{d}}$ & 32 \\
\hline 5 & 32 & $32^{\mathrm{c}}$ & $\mathrm{No}^{\mathrm{a}}$ & 3 & 1.2 & 6.5 & $7.4 \pm 3.5^{\mathrm{d}}$ & 28 \\
\hline 6 & 32 & 35 & Yes & 10 & 1.6 & 6.8 & $6.0 \pm 3.2$ & 28 \\
\hline 7 & 31 & $31^{\mathrm{c}}$ & Yes & 3 & 1.2 & 7.0 & $5.3 \pm 2.8$ & 20 \\
\hline 8 & 31 & 32 & $\mathrm{No}^{\mathrm{a}}$ & 24 & $6.0^{\mathrm{b}}$ & 5.0 & $8.2 \pm 2.2$ & 16 \\
\hline 9 & 32 & $37^{1 / 2}$ & Yes & 30 & 1.6 & 6.0 & $7.0 \pm 2.2$ & 24 \\
\hline 10 & 33 & 38 & Yes & 120 & 1.4 & 6.0 & $6.5 \pm 2.9$ & 28 \\
\hline
\end{tabular}

${ }^{\text {a }}$ multiple congenital malformations - all deaths occurred after delivery in the perinatal period

${ }^{\mathrm{b}}$ ritodrine infusion; all the rest salbutamol infusion

${ }^{\mathrm{c}} \mathrm{B}$-sympathomimetic infusion failed to prevent delivery

${ }^{\mathrm{d}}$ post ketoacidosis

\section{Results}

Table 1 provides a summary of the ten cases. In all cases high insulin infusion rates were required to maintain acceptable blood glucose concentrations, particularly at the higher rates of salbutamol infusion. Insulin infusion rate had to be adjusted frequently, sometimes hourly, to maintain blood glucose below $7 \mathrm{mmol} / 1$ during $\beta$-sympathomimetic infusion. Acceptable blood glucose levels were maintained throughout in 8 cases. The mean blood glucose in these 8 cases was $5.3 \pm 2.8 \mathrm{mmol} / 1$ to $8.2 \pm$ $2.2 \mathrm{mmol} / 1$ (range $2-12 \mathrm{mmol} / \mathrm{l}$ ). Table 1 gives the individual means \pm SD for these cases.

Of the two other cases one was transferred from another hospital having developed ketoacidosis during salbutamol infusion and the other developed ketoacidosis whilst under our care. The first patient had a blood glucose level of $30 \mathrm{mmol} / 1$ and a bicarbonate of $10 \mathrm{mmol} / 1$. The second patient had a blood glucose level of up to $16 \mathrm{mmol} / \mathrm{l}$ with a bicarbonate of $14 \mathrm{mmol} / 1$. In both, ketoacidosis resulted from starting at too low a rate of insulin infusion $(2 \mathrm{U} / \mathrm{h}$ and $8 \mathrm{U} / \mathrm{h}$ respectively), and was corrected by increasing the infusion rate (to a maximum of $32 \mathrm{U} / \mathrm{h}$ and $28 \mathrm{U} / \mathrm{h}$ respectively).

In 6 cases B-sympathomimetic infusion was discontinued and then re-started. The infusion was stopped for between 1 and 20 hours in these cases. An increased amount of insulin had still to be infused during this time, because of the concurrent administration of dexamethasone. The mean blood glucose between $\beta$-sympathomimetic infusions in these 6 cases was $5.3 \pm 0.9$ to $6.1 \pm 2.4 \mathrm{mmol} / \mathrm{l}$ (range $2-10 \mathrm{mmol} / \mathrm{l}$ ). All cases, between $\beta$-sympathomimetic infusion, were well maintained with an insulin infusion rate varying between 2 and $6 \mathrm{U} / \mathrm{h}$.

Mean pre-pregnancy requirement of insulin was $52 \pm 6.1$ (range 42-62) U/day. Mean insulin requirement in the days immediately before the development of premature labour was $104 \pm 15.2$ (range 84-120) U/day. Both of these values were much lower than the insulin requirements during $\beta$ sympathomimetic infusion when a maximum range of 8 to $32 \mathrm{U} / \mathrm{h}$ of insulin was needed. The post $\beta$-sympathomimetic infusion insulin requirement was very similar to the pre-infusion values, $55.7 \pm 7.8$ (range 40-72) U/day if the pregnancy continued. In the cases where $\beta$-sympathomimetic infusion failed to prevent labour continuing then immediately after delivery the insulin dosage reverted back to pre-pregnancy levels.

In all cases during $\beta$-sympathomimetic infusion, there was a fall in plasma potassium to below the normal range despite administration of potassium supplements. Mean plasma potassium fell from $4.5 \mathrm{mmol} / \mathrm{l}$ to $2.7 \mathrm{mmol} / \mathrm{l}$, the maximal decrease being from 4.5 to $2.0 \mathrm{mmol} / 1$.

No acute adverse effects on the foetuses were observed, and in only one patient did the $\beta$-sym- 
pathomimetic infusion rate have to be decreased because of maternal side effects. In this patient the heart rate increased from 70 to 150 beats $/ \mathrm{min}$.

To illustrate the practical management one case is described in more detail.

\section{Case 10}

B. W., a 26 year old uncomplicated insulin dependent diabetic of 12 years duration, presented at 9 weeks of pregnancy. There had been two previous foetal losses at 32 weeks and 37 weeks of pregnancy. In both pregnancies she had suffered from polyhydramnios and hypertension from 28 weeks. The first baby had died from respiratory distress syndrome, and the second from Pseudomonas pneumonia during the first neonatal week. Her diabetes had been well controlled during the present pregnancy with a twice daily soluble/isophane insulin mixture. At 33 weeks of pregnancy she developed premature uterine contractions.

In order to delay delivery salbutamol infusion was begun and insulin was infused at a rate of $16 \mathrm{u} / \mathrm{h}$. Dexamethasone $4 \mathrm{mg}$ IM eight hourly for $48 \mathrm{~h}$ was given concurrently. Blood glucose control was maintained as shown (Fig. 1) for $120 \mathrm{~h}$. Contractions ceased and the pregnancy continued. No maternal problems were recorded during the salbutamol infusion, although plasma potassium fell from 3.7 to $2.7 \mathrm{mmol} / 1$ despite potassium supplements. A live healthy baby weighing $3.6 \mathrm{~kg}$ was delivered by elective Caesarean section at 38 weeks.

\section{Discussion}

The most commonly used $\beta$-sympathomimetic agents are salbutamol, ritodrine, isoxuprine and terbutaline. These drugs have pronounced effects on glucose metabolism $[4,5,6]$, possible mechanisms including hepatic glycogenolysis, and peripheral insulin resistance resulting in an inhibition of glucose uptake and utilisation. A rapid transient rise in plasma nonesterified fatty acid and blood ketone body levels may also occur $[5,6]$; steroids increase gluconeogenesis.

Maintenance of blood glucose concentration within acceptable limits is possible if the effects of $\beta$ sympathomimetic infusion are anticipated. This is achieved by starting at a high rate of insulin infusion. On the basis of our experience we would suggest that $16 \mathrm{U} / \mathrm{h}$ would be a reasonable starting rate (one case developed mild ketoacidosis on $8 \mathrm{U} / \mathrm{h}$ ) and this can be further adjusted depending on blood glucose levels obtained. In this way loss of diabetic control can be averted. The insulin infusion rate required is much greater than that used for the management of labour or surgery, or indeed ketoacidosis $[8,9]$.

One of our 10 cases was referred from another hospital in severe ketoacidosis and one developed a mild ketoacidosis whilst under our care. Both developments occurred because of a failure to infuse enough insulin from the beginning of $\beta$-sympathomimetic infusion. These cases illustrate the

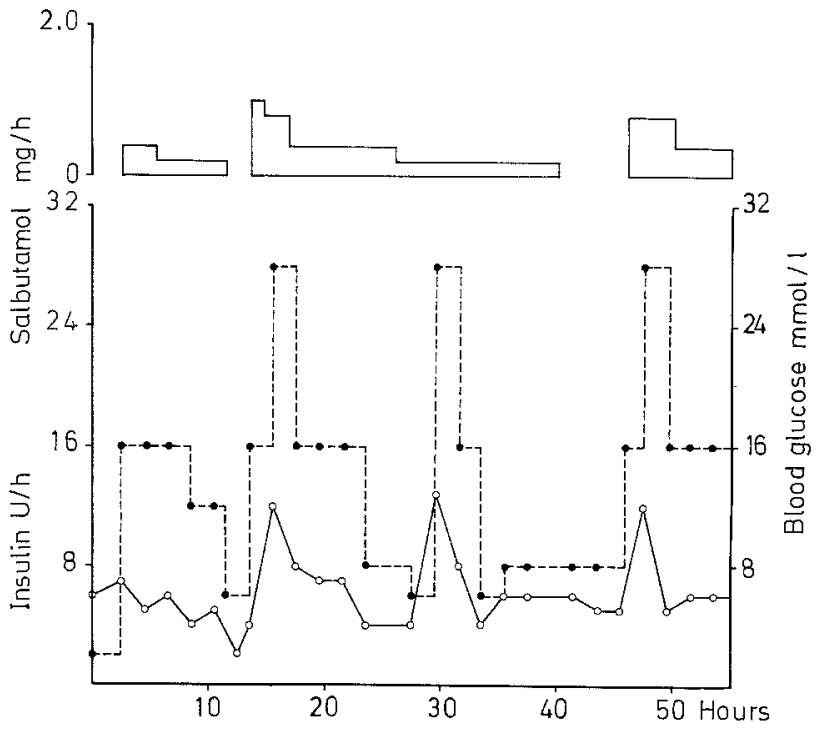

Fig. 1. Summary of the management of premature labour in case 10 , during and between infusion of salbutamol over 55 hours (and coincident with dexamethasone $4 \mathrm{mg} \mathrm{IM}$ every 8 hours for the first 48 hours). Insulin infusion rate, blood glucose concentration and salbutamol infusion rate $\mathrm{v}$ time $(\mathrm{h})$ are shown. Salbutamol infusion was continued, at an infusion rate of $0.4-0.8 \mathrm{mg} / \mathrm{h}$, for a further 65 hours. During this time blood glucose concentration was maintained between 3 and $8 \mathrm{mmol} / 1$ with an insulin infusion rate varying between 8 and $16 \mathrm{U} / \mathrm{h}$. $\mathrm{O}-\mathrm{O}$ Blood glucose; Insulin

absolute necessity of starting at a high rate of insulin infusion. $\beta$-sympathomimetic infusion is a relatively new method of management of premature labour and certainly in diabetic patients serious metabolic problems have been reported $[9,10]$. Regular subcutaneous or even intramuscular insulin would probably be unsuitable for optimal control.

There was no apparent correlation between the pre-pregnancy or the pregnancy dose of insulin with the amount of insulin required during $\beta$-sympathomimetic infusion to maintain acceptable blood glucose concentrations. The duration of diabetes and the presence or absence of microangiopathy also appeared to be unrelated to the amount of insulin required during $\beta$-sympathomimetic infusion. Although total carbohydrate intake varied between patients this in practice proved unimportant owing to the flexibility of the regime.

A similar regime can be used to maintain blood glucose concentration during dexamethasone administration alone. The only difference is that insulin requirements are less than during $\beta$-sympathomimetic infusion.

Plasma potassium may fall during $\beta$-sympathomimetic infusion $[4,11]$. There is, however, no significant increase in urinary potassium excretion [11] and presumably there is, therefore, a redistribu- 
tion from the extracellular to the intracellular compartment. This is supported by in vitro studies [12]. In view of the fairly marked lowering of plasma potassium in all our cases it would probably be wise to infuse more than $80 \mathrm{mmol} / 24 \mathrm{~h}$ and we would suggest that $100-120 \mathrm{mmol} / 24 \mathrm{~h}$ would be more appropriate. For simplicity, we suggest a standard amount of potassium, rather than a varying dose according to the rate of $\beta$-sympathomimetic infusion, with regular checks ( 3 hourly) on the plasma potassium concentration.

Maternal side-effects such as tachycardia, widened pulse pressure, sweating, nausea, vomiting and fine tremor have been described $[6,13,14]$. In our experience these rarely present problems. In one case the salbutamol infusion rate had to be lowered because of intense tachycardia.

A slight increase in foetal heart rate and beat-tobeat variation has been described [11], but in none of our cases were any ill effects on the foetus recorded.

The treatment of premature labour by the use of $\beta$-sympathomimetics agents is effective. Premature delivery was delayed in eight of our patients. Respiratory distress syndrome occurred only in case 7 and this baby survived. Three deaths due to multiple congenital abnormalities occurred after delivery. The fact that labour starts prematurely may be an indication of a congenital defect in the foetus.

The management of premature labour in diabetes presents problems which can be overcome by the simple, flexible regime which we describe. It should be emphasised that although this regime can be followed in most hospitals it is better if the patient is managed in a hospital with an intensive care baby unit so that if the treatment fails and a premature baby is delivered, expert care and nursing are available.

Acknowledgements. The authors would like to thank Dr. D. A. Pyke, Dr. P. J. Watkins and Dr. R. D. G. Leslie of the Diabetic Department and Mr. M. Brudenell of the Obstetric Department, King's College Hospital, for their help and encouragement in the production of this paper. They would also like to thank Mrs. A. Spink for typing the manuscript.

S. M. S. is supported by an M. R. C. grant.

\section{References}

1. Liggins G C, Vaughan G S (1973) Intravenous infusion of salbutamol in the management of premature labour. J Obstet Gynaecol Br Commonw 80: 29-32

2. Ingermarsson I (1976) Effect of terbutaline on premature labour. Am J Obstet Gynecol 125: 520-524

3. Lauersen N H, Merkatz I R, Tejani N, Wilson K H, Roberson A, Mann L I, Fuchs F (1977) Inhibition of premature labour: A multicentre comparison of ritodrine and ethanol. Am J Obstet Gynecol 127: 837-845

4. Thomas D J B, Dove A F, Alberti K G M M (1977) Metabolic effects of salbutamol infusion during premature labour. $\mathrm{Br} \mathrm{J}$ Obstet Gynaecol 84: 497-499

5. Lunell NO, Joelsson I, Larsson A, Persson B (1977) The immediate effect of a B-adrenergic agonist (salbutamol) on carbohydrate and lipid metabolism during the third trimester of pregnancy. Acta Obstet Gynecol Scand 56: 475-478

6. Fredholm B B, Lunell N O, Persson B, Wager J(1978) Actions of salbutamol in late pregnancy: Plasma cyclic AMP, insulin and C-peptide, carbohydrate and lipid metabolites in diabetic and non-diabetic women. Diabetologia 14: 235-242

7. White P (1971) Pregnancy and diabetes. In: Marble A, White P, Bradley R F, Krall L P (eds) Joslin's diabetes mellitus, 11th ed. Lea \& Febiger, Philadelphia, p 588

8. Page M McB, Alberti K G M M, Greenwood R, Gumaa KA, Hockaday T D R, Lowy C, Nabarro J D N, Pyke D A, Sönksen P H, Watkins P J, West TET (1974) Treatment of diabetic coma with continuous low dose infusion of insulin. $\mathrm{Br}$ Med $\mathrm{J}$ II: $687-690$

9. Leslie R D G, Mackay J D 61978) Intravenous insulin infusion in diabetic emergencies. Br Med J II: 1343-1344

10. Thomas D J B, Gill B, Brown P, Stubbs WA (1977) Salbutamol-induced diabetic ketoacidosis. Br Med J II: 438

11. Smith S K, Thompson D (1977) The effect of intravenous salbutamol upon plasma and urinary potassium during premature labour. Br J Obstet Gynaecol 84: 344-347

12. Wang $P$, Clausen $T$ (1976) Treatment of attacks in hyperkalaemic familial periodic paralysis by inhalation of salbutamol. Lancet I: 221-223

13. Lipshitz J, Baillie P (1973) Uterine and cardiovascular effects of beta ${ }_{2}$ - selective sympathomimetic drugs administered as an intravenous infusion. S Afr Med J (Suppl S Afr J Obstet Gynaecol) 69-73

14. McDevitt D G, Wallace R J, Roberts A, Whitfield C R (1975) The uterine and cardiovascular effects of salbutamol and practolol during labour. Br J Obstet Gynaecol 82: 442-448

Received: June 15, 1979, and in revised form: November 26, 1979

Dr. A. H. Barnett

Diabetic Clinic, King's College Hospital

Denmark Hill, London SE5 9RS, England 